\title{
PENELITIAN TINDAKAN KELAS TERHADAP SISWA PAUD BUNDA HAJAR MELALUI KETERAMPILAN MENYIMAK, MEMBACA, BERBICARA DAN MENULIS
}

\author{
Tania Intan ${ }^{1}$, Sri Rijati², Nurul Hikmayaty ${ }^{3}$ \\ ${ }^{1}$ Universitas Padjadjaran. Email: tania.intan@unpad.ac.id \\ ${ }^{2}$ Universitas Padjadjaran. Email: sri.rijati@unpad.ac.id \\ ${ }^{3}$ Universitas Padjadjaran. Email: nurul.h.saefullah@unpad.ac.id
}

\begin{abstract}
This paper reveals the activity of Pengabdian Pada Masyarakat (PPM) - Community Service - that we have done on the theme of Increasing the Interest in Reading of the Students of Bunda Hajar Early Childhood Education through the Competences of Listening, Reading, Speaking, and Writing. The aimed public is children in early childhood (4-7 years old) who attend the Bunda Hajar Early Childhood Education, in the village of Sukanegla Jatinangor, in the entourage of Universitas Padjadjaran. The goal of this community service is to increase the reading interest of children in early childhood as an effort to elevate the quality of human resources in the future. In this activity, those who take part are lecturers, students, and the society. The result of this service shows thatthe aimed public has an increasein reading interests and an expansion of knowledge.
\end{abstract}

Keywords: interest, reading, children in early childhood

\begin{abstract}
ABSTRAK
Tulisan ini berisi paparan mengenai kegiatan Pengabdian Pada Masyarakat (PPM) yang telah dilakukan dengan tema Peningkatan Minat Baca Siswa PAUD Bunda Hajar melalui Keterampilan Menyimak, Membaca, Berbicara dan Menulis. Publik yang menjadi sasaran adalah anak-anak berusia dini (4-7 tahun) yang mengikuti pendidikan di PAUD Bunda Hajar yang terletak di Desa Sukanegla Jatinangor, berada di sekitar kampus Universitas Padjadjaran. Tujuan pelaksanaan kegiatan PPM adalah untuk meningkatkan minat baca anak usia dini sebagai upaya peningkatan kualitas sumber daya manusia di masa depan. Dalam kegiatan ini, pihak-pihak yang terlibat adalah dosen, mahasiswa, dan masyarakat. Hasil kegiatan menunjukkan anak-anak yang menjadi sasaran mengalami peningkatan minat baca dan penambahan pengetahuan.
\end{abstract}

Kata Kunci : minat, membaca, anak usia dini

\section{PENDAHULUAN}

Kondisi sumber daya manusia merupakan ukuran maju atau tidaknya suatu bangsa. Tanpa SDM yang berkualitas, suatu bangsa tidak akan dapat bersaing dengan bangsa lain dalam era globalisasi. Menurut sejumlah riset, SDM yang ada di Indonesia masih berada pada tingkat rendah dan justru mengalami proses penurunan dari tahun ke tahun. United Nations Development Program pada tahun 2000 melaporkan bahwa 
Human Development Index Indonesia berada pada peringkat 109 dari 174 negara (Tilaar, 2002:48).

Salah satu faktor penyebab rendahnya Indeks Pembangunan Manusia di Indonesia adalah rendahnya kualitas pendidikan, yang juga berpengaruh langsung pada berbagai bidang. Keadaan tersebut lebih diperburuk dengan masih dominannya budaya tutur (lisan) daripada budaya baca. Budaya ini menjadi kendala utama dalam meningkatkan kualitas sumber daya masyarakat yang seharusnya mampu mengembangkan diri dalam menambah ilmu pengetahuan secara mandiri melalui kegiatan membaca. Oleh karena itu, diperlukan keterlibatan semua pihak dalam upaya pengembangan minat baca, baik dari kalangan pelajar maupun masyarakat umum.

Kebiasaan membaca perlu dimulai dari usia dini sejak di rumah, di sekolah dasar, dan terus dikembangkan dan ditingkatkan intensitasnya mulai sekolah menengah pertama dan atas, hingga perguruan tinggi. Tanpa kebiasaan membaca, maka akan sangat sulit bagi seseorang untuk menguasai ilmu pengetahuan dan teknologi yang sebagian besar berada dalam buku/ berupa teks. Kebiasaan membaca dan penguasaan Iptek bagaikan dua sisi mata uang yang tidak dapat dipisahkan. Minat baca, buku dan perpustakaan adalah tiga elemen pokok dalam suatu sistem pendidikan yang dapat menciptakan kualitas sumber daya manusia. Sebuah negara yang kaya dengan SDM akan lebih unggul daripada suatu negara yang kaya karena sumber daya alam.

Atas dasar pemikiran tersebut, program PPM dengan tema Peningkatan Minat Baca Siswa PAUD Bunda Hajar Melalui Keterampilan Menyimak, Membaca, Berbicara dan Menulis diselenggarakan sebagai bentuk partisipasi aktif sivitas akademika Universitas Padjadjaran dalam membantu memecahkan masalah-masalah yang dihadapi masyarakat di sekitar kampus. Sebagai tempat anak-anak bangsa mengembangkan diri dan meningkatkan mutu pribadinya, Pendidikan Anak Usia Dini (PAUD) memiliki peran yang sangat penting bagi generasi penerus bangsa. Lokasi kegiatan PPM yang dipilih adalah PAUD Bunda Hajar, Sukanegla Desa Hegarmanah, Kecamatan Jatinangor yang letaknya tidak jauh dari kampus Universitas Padjadjaran.

\section{Profil PAUD Bunda Hajar}

Sebagai wujud kepedulian terhadap kondisi pendidikan, Badan Eksekutif Mahasiswa Keluarga Mahasiswa (BEM Kema) Unpad bekerja sama dengan Pendidikan Anak Usia Dini (PAUD) Bunda Hajar mendirikan Taman Ilmu Unpad atau juga sering disebut Taman Ilmu Bunda Hajar. Taman Ilmu ini mengadakan kegiatan belajar mengajar di bawah asuhan mahasiswa Unpad bagi murid-murid Taman Kanak-Kanak (TK), Sekolah Dasar (SD), dan Sekolah Menengah Pertama (SMP) di daerah sekitar Dusun Sukanegla dan Dusun Sukawening Jatinangor. Tujuan dari didirikannya Taman Ilmu adalah untuk membantu mengembangkan potensi anak yang kurang mampu secara ekonomi dalam berbagai bidang yang diminati, serta membuka dan memberikan jalan pada anak bangsa untuk mencapai cita-citanya.

Para pengajar Taman Ilmu Bunda Hajar yang memberikan pendidikan gratis di luar sekolah ini berasal dari gabungan mahasiwa/ mahasiswi Universitas Padjadjaran dan pemuda Desa Sukanegla. Kegiatan Belajar Mengajar (KBM) dilaksanakan setiap hari Jum'at-Sabtu pukul 14.00-16.00 WIB dan hari Minggu pukul 07.00-sampai dengan selesai 
berupa pemberian materi mengenai akademik, non akademik dan olahraga. Dalam pengajarannya, KBM di Taman Ilmu memiliki perbedaan dalam cara pengajaran dengan sekolah formal. Taman Ilmu cenderung menggunakan kedekatan antara anak-anak dengan pengajar dengan batas-batas yang wajar dalam penyampaian materinya. Cara ini dapat dikatakan dengan sebutan fun learning. Penyampaian materi dapat dilakukan melalui permainan yang berhubungan dengan materi yang diajarkan, kunjungan ke tempat-tempat yang berhubungan dengan materi (kebun binatang, museum, pusat budaya). KBM yang dilakukan di kelas atau di luar kelas secara komunikatif dapat menarik perhatian siswa Taman Ilmu untuk mempelajari materi yang diajarkan serta aplikasi metode-metode yang kreatif untuk menarik perhatian siswa untuk belajar.

Taman Ilmu memiliki dua buah sekretariat yang terletak di dalam kampus dan di luar kampus Universitas Padjadjaran. Sekretariat pertama berada di Sekretariat BEM KEMA UNPAD yang terletak di kompleks UKM UNPAD Jatinangor dan sekretariat kedua terletak di PAUD Bunda Hajar yang terletak di dusun Sukanegla, Jatinangor.

Dalam proses pembelajaran, untuk setiap pengajar dan anak-anak, dipinjamkan buku-buku untuk menunjang KBM yang dapat diambil di sekretariat kedua Taman Ilmu. Taman Ilmu memiliki kurang lebih 320 judul buku dengan masing-masing buku terdiri dari 5-10 eksemplar. Buku-buku tersebut terdiri dari kamus, buku pelajaran, atlas, cerita bergambar dan lain-lain yang merupakan sumbangan dari berbagai pihak di dalam kampus. Selain itu, Taman Ilmu juga memiliki beberapa alat peraga yang berguna dalam KBM seperti peta, globe dan kerangka manusia. Relawan muda atau pengajar Taman Ilmu Unpad 2015 yang berpartisipasi dalam kegiatan PPM berjumlah 20 orang mahasiswa. mereka berasal dari berbagai fakultas di lingkungan Universitas Padjadjaran.

\section{METODE PELAKSANAAN}

Metode yang digunakan dalam kegiatan Pengabdian Pada Masyarakat ini meliputi tiga tahapan, yaitu persiapan, pelaksanaan, serta evaluasi.

1. Tahap Persiapan

Pada tahap ini dilakukan survey ke lokasi kegiatan, yaitu PAUD Bunda Hajar di Desa Hegarmanah Jatinangor untuk mendapatkan gambaran yang obyektif dan faktual dari publik sekaligus mitra kegiatan Pengabdian Pada Masyarakat (PPM) tersebut. Selanjutnya dibuat profil aktual dari lokasi kegiatan sebagai bahan untuk penyusunan laporan. Setelah itu dilakukan perencanaan kegiatan, yang meliputi jenis dan jadwal kegiatan, pemilihan dan penentuan media dan materi setiap kegiatan, serta penanggung jawab dan pelaksana. Rencana kegiatan ini disusun dalam bentuk modul kegiatan.

2. Tahap Pelaksanaan

Pada tahap pelaksanaan, kegiatan dibedakan menjadi tiga jenis kegiatan, yaitu:

a. Koordinasi internal, yang dilakukan bersama oleh tim PPM dengan para mahasiswa yang menjadi bagian dari Taman Ilmu Unpad. Di dalam kegiatan ini, dilakukan pertemuan-pertemuan dan diskusi.

b. Kegiatan pengumpulan data yang dilakukan dalam kelompok-kelompok kerja yang membahas aspek berbeda. 
c. Kegiatan di lokasi yang meliputi pelatihan dan penyampaian informasi untuk materi yang bersifat umum kepada khalayak yang hadir (pihak sekolah, siswa dan orang tua, mahasiswa (Taman Ilmu Unpad), serta tim pelaksana PPM. Selanjutnya permainan-permainan dilakukan dengan para siswa PAUD berkaitan dengan peningkatan keterampilan berbahasa yang meliputi Menyimak, Membaca, Berbicara, dan Menulis. Setelah itu, metode dialogis yang bersifat tanya jawab dan diskusi diadakan oleh tim PPM dengan pihak orang tua, sekolah dan mahasiswa tentang dasar-dasar pengelolaan perpustakaan dan upaya lanjutan untuk peningkatan minat baca siswa PAUD. Selanjutnya dilakukan revitalisasi perpustakaan PAUD Bunda Hajar dan Taman Ilmu, berupa inventarisasi serta penambahan koleksi bacaan.

3. Tahap Evaluasi

Tahapan terakhir meliputi evaluasi kegiatan yang telah dilakukan untuk mengukur keberhasilan yang telah dicapai sekaligus kekurangan yang masih terjadi, untuk kemudian dijadikan saran bagi penyelenggaraan kegiatan sejenis yang akan dilakukan selanjutnya. Setelah itu, hasil evaluasi disusun sebagai laporan kegiatan Pengabdian Pada Masyarakat (PPM).

\section{HASIL DAN PEMBAHASAN}

Semua kegiatan diselenggarakan sesuai dengan langkah-langkah yang sudah ditetapkan, yang meliputi persiapan, pelaksanaan, evaluasi dan pelaporan. Membaca merupakan proses ingatan, penilaian, pemikiran, penghayalan, pengorganisasian pemikiran dan pemecahan masalah. Membaca juga merupakan alat untuk belajar dan untuk memperoleh kesenangan, informasi yang terkandung dalam suatu bacaan sehingga didapat pengetahuan dan pengalaman untuk memenuhi kebutuhan manusia atau seseorang.

Somadayo (2011:4) mengungkapkan bahwa membaca adalah suatu kegiatan interaktif untuk memetik serta memahami arti yang terkandung di dalam bahan tulis. Pendapat tersebut didukung Henry Guntur Tarigan (1985: 9) yang menjelaskan bahwa membaca merupakan proses memahami pola-pola bahasa dari gambaran tulisannya. Dari beberapa pendapat di atas dapat disimpulkan bahwa membaca adalah proses asosiasi huruf, penerjemahan, dan pemahaman makna isi bacaan.

Budaya baca merupakan persyaratan yang sangat penting dan mendasar yang harus dimiliki oleh setiap warga negara apabila kita ingin menjadi bangsa yang maju. Melalui budaya baca, mutu pendidikan dapat ditingkatkan sehingga pada gilirannya dapat meningkatkan kualitas sumber daya manusia. Melalui budaya baca pula pendidikan seumur hidup (long life education) dapat diwujudkan. Karena dengan kebiasaan membaca, seseorang dapat mengembangkan dirinya sendiri secara terusmenerus sepanjang hidupnya.

Dalam era informasi sekarang ini, mustahil kemajuan dapat dicapai oleh suatu bangsa, jika bangsa itu tidak memiliki budaya baca. Secara singkat manfaat membaca bagi individu yang bersangkutan sebagai berikut :

1. Dapat merupakan cara untuk mendalami suatu masalah dengan mempelajari 
sesuatu persoalan hingga dapat menambah pengetahuan yang berhubungan dengan peningkatan kecakapan.

2. Untuk dapat menambah pengetahuan umum tentang sesuatu persoalan.

3. Untuk mencari nilai-nilai hidup sebagai kepentingan pendidikan diri sendiri.

4. Untuk mengisi waktu luang dangan mengamati seni sastra ataupun cerita-cerita fiksi yang bermutu.

Manfaat membaca bagi perkembangan masyarakat antara lain :

1. Meningkatkan pengetahuan umum masyarakat;

2. Meningkatkan kecerdasan masyarakat sehingga mempunyai kemampuan yang lebih besar untuk mengembangkan diri;

3. Dapat digunakan sebagai media penerangan serta pengarahan terhadap perkembangan masyarakat;

4. Menumbuhkan sikap kritis sehingga mempu mengadakan koreksi mengenai adanya hal-hal yang merugikan masyarakat;

5. Sebagai media penyampaian gagasan-gagasan baru yang berguna untuk meningkatkan perkembangan masyarakat.

\section{Membaca sebagai Konstruksi Sosial}

Kehidupan seorang individu di masyarakat tidak terlepas dari bagaimana ia dibentuk atau dikonstruksi sedari kecil oleh lingkungannya. Seperti yang dijelaskan oleh Berger \& Luckmann (1990), konstruksi sosial individu terjadi melalui eksternalisasi, objektivasi, dan internalisasi. Eksternalisasi adalah situasi di mana individu dibentuk oleh lingkungan tempatnya berada dan ia harus menyesuaikan dengan lingkungannya tersebut agar dapat diterima. Seorang anak yang mengalami pembiasaan membaca dalam lingkungan keluarganya akan terus membawa kegiatan tersebut dalam kesehariannya hingga dewasa. Bila orang tua misalnya memberi contoh membaca koran, majalah, dan sebagainya, maka anak juga biasanya akan meniru kebiasaan tersebut. Demikian pula halnya bila orang tua menyediakan sarana berupa buku-buku dan ruangan yang memadai untuk membaca.

Kemudian proses konstruksi sosial yang kedua adalah objektivasi. Objektivasi adalah proses di mana individu memahami perilaku orang lain yang dilakukan secara terus menerus dan berulang-ulang sehingga dikenali sebagai suatu kebiasaan. Kemampuan ekspresi diri manusia mampu mengadakan obyektivasi (objectivation), artinya ia memanifestasikan diri dalam produk-produk kegiatan manusia yang tersedia, baik bagi produsen-produsennya maupun bagi orang lain sebagai unsur-unsur dari dunia bersama (ibid: 49). Dengan kebiasaan membaca dari rumah, anak akan mencari dan menemukan lingkungan yang mendukung minatnya tersebut. Ia akan mudah merasa akrab dengan perpustakaan di sekolah atau pun tempat-tempat umum lain yang menyediakan bacaan. Pengembangan kebiasaan membaca dari rumah ke wilayah yang lebih luas ini tentunya akan berpengaruh kepada jenis dan jumlah bacaan.

Proses ketiga dalam konstruksi sosial adalah internalisasi. Titik awal individu untuk menjadi anggota masyarakat adalah internalisasi yaitu pemahaman atau penafsiran yang langsung dari suatu peristiwa obyektif sebagai pengungkapan suatu makna (ibid: 186). Internalisasi adalah proses di mana individu menerima berbagai pengetahuan dari luar dirinya untuk kemudian membuat dirinya sendiri memahami makna semua pengetahuan 
tersebut dan menggunakannya untuk mengkonstruksi atau membentuk dirinya sendiri sehingga individu bisa memiliki perilaku dan kepribadian sebagaimana dengan yang diinginkannya. Hasil membaca dapat membentuk paradigma tertentu sebagai bentuk resepsinya.

Proses untuk mencapai tahap internalisasi adalah sosialisasi. Sosialisasi dapat didefinisikan sebagai pengimbasan individu secara komprehensif dan konsisten ke dalam dunia obyektif suatu masyarakat atau salah satu sektornya (ibid: 187). Sosialisasi terbagi menjadi dua yakni sosialisasi primer dan sosialisasi sekunder. Sosialisasi primer adalah sosialisasi pertama yang dialami individu dalam masa kanak-kanak, yang dengan itu ia menjadi anggota masyarakat. Sosialisasi primer menciptakan di dalam kesadaran anak suatu abstraksi yang semakin tinggi dari peranan-peranan dan sikap orang-orang lain tertentu ke peranan-peranan dan sikap-sikap pada umumnya (ibid: 190). Karena dalam sosialisasi primer, individu tidak bisa memilih orang-orang yang mempengaruhi kehidupan awalnya, maka yang paling berperan adalah orang tua dan keluarga. Di dalam keluarga inilah pertama kali individu dikenalkan pada hal-hal yang terjadi di masyarakat dimana nantinya individu akan bergabung menjadi bagiannya.

\section{Budaya Baca di PAUD}

Pendidikan Anak Usia Dini merupakan salah satu bentuk penyelenggaraan pendidikan yang menitik beratkan pada peletakan dasar ke arah pertumbuhan, perkembangan fisik (koordinasi motorik kasar dan halus), dan kecerdasan (daya pikir, daya cipta, kecerdasan emosi, kecerdasan spiritual) (Herawati, 2005: 7). Hal ini dipertegas dalam UU Sisdiknas 2003 Bab 1 Pasal 1 Ayat 14 yang menyatakan bahwa Pendidikan Anak Usia Dini adalah salah satu pembinaan yang ditujukan kepada anak sejak lahir sampai dengan usia enam tahun yang dilakukan melalui pemberian rangsangan pendidikan untuk membantu pertumbuhan dan perkembangan jasmani dan rohani agar anak memiliki kesiapan dalam memasuki pendidikan lebih lanjut. Pendidikan yang diberikan pada anak usia dini sebaiknya disesuaikan dengan usia dan tahap perkembangannya (dalam Arum Marlinawati, 2013: 16).

Sebelum pelaksanaan kegiatan Pengabdian Kepada Masyarakat di Taman Ilmu PAUD Bunda Hajar dengan tema Peningkatan Minta Baca Siswa PAUD Bunda Hajar Melalui Keterampilan Menyimak, Membaca, Berbicara, dan Menulis, telah dilakukan berbagai tahap persiapan. Tahap-tahap ini meliputi pemilihan tim peneliti dan pembagian tugas-tugas. Selanjutnya tim peneliti menghubungi kepala sekolah Taman Ilmu Unpad, yaitu Riki Nawawi untuk berkoordinasi sehubungan dengan diadakannya kegiatan tersebut. Dari beberapa pertemuan yang dilakukan tim peneliti dengan kepala sekolah Taman Ilmu, didapatkan berbagai informasi mengenai PAUD Bunda Hajar yang menjadi dasar penentuan waktu, tempat dan peserta kegiatan PPM tersebut.

Tahap selanjutnya yaitu mempersiapkan materi penyuluhan yang akan diberikan kepada para siswa Taman Ilmu. Materi penyuluhan yang dipersiapkan terdiri dari manfaat membaca, cara membaca yang efektif dan praktik membaca. Terakhir, tim peneliti juga mempersiapkan beberapa bingkisan untuk dibagikan pada para peserta sebagai pemberi semangat dan kenang-kenangan. 
Setelah semua tahap persiapan dilakukan dengan matang, Pengabdian Kepada Masyarakat di Taman Ilmu dan PAUD Bunda Hajar selesai dilaksanakan pada hari Minggu, 29 Oktober 2015 pukul 13.00-15.00 WIB. Peserta yang mengikuti kegiatan ini adalah 30 siswa PAUD Bunda Hajar, TK dan SD kelas 1 yang belum terlalu mahir membaca sehingga kegiatan ini dapat menjadi latihan tersendiri bagi mereka. Dengan bimbingan tim peneliti, para peserta diajak untuk mengenal dan membaca beberapa buku cerita yang menarik.

Pendidikan yang baik dimulai sedini mungkin bagi anak karena merupakan pondasi untuk menentukan masa depannya kelak. Anak berusia dini terlebih dahulu diperkenalkan pada buku yang sesuai dengan usianya, yang tentunya berbeda dengan buku remaja atau orang dewasa. Buku untuk anak-anak biasanya penuh dengan gambargambar yang menarik dengan sedikit tulisan sehingga anak-anak senang melihat buku dan berusaha untuk membacanya, walau untuk pemula biasanya akan kesusahan dalam membaca. Tugas guru atau pendidik dalam hal ini menjadi fasilitator atau teman untuk membacakan cerita. Dalam hal ini, William S. Gray (dalam Pujiastuti, 2010) menekankan bahwa membaca tidak lain daripada kegiatan pembaca dalam menerapkan sejumlah keterampilan mengolah tuturan tulisan atau bacaan yang dibacanya dalam rangka memahami bacaan. Ditinjau dari kemampuan membaca, kemungkinan anak-anak akan menemukan kegembiraan tetapi hal ini sangat bergantung pada asuhan dan arahan orang tua dan guru. Mengarahkan anak untuk gemar membaca biasanya dapat dilakukan dengan menggunakan dongeng, karena cerita semacam itu pasti menjadi hal yang sangat menarik dan sesuai dengan alam pikiran mereka.

Penggunaan buku cerita bergambar dapat menarik perhatian anak sehingga, minat membaca menjadi lebih tinggi. Gambar dapat memberikan stimulus yang menarik perhatian anak untuk melihatnya, selain itu, gambar juga berfungsi sebagai objek bantu berpikir yang nyata dan media pengingat. Untuk kegiatan ini, tim pelaksana PPM membawa sejumlah buku cerita bergambar untuk melengkapi koleksi perpustakaan PAUD Bunda Hajar. Beberapa judul di antaranya adalah : Si Jubah Merah, Putri Shirayuki, Burung Biru, Sepatu Merah, Gadis Kecil, dan sebagainya.

Tahap-tahap dalam kegiatan dimulai dari menyimak, membaca, berbicara, dan menulis. Awalnya anak-anak dibacakan dongeng dari buku yang mereka pilih. Pembacaan dilakukan secara lambat, teratur, dan bila diperlukan diulang pada beberapa bagian. Anak-anak menyimak dengan baik. Selanjutnya mereka mencoba membaca sendiri buku tadi. Meskipun terdapat sejumlah kesulitan teknis terkait keterampilan membaca yang belum dikuasai, anak-anak berusaha memahami huruf-huruf dan katakata yang tertulis. Proses ini dilakukan berulang pada buku-buku lain.

Kegiatan kemudian dilanjutkan dengan tanya jawab di antara tim PPM dengan anak-anak sehubungan dengan isi cerita dari buku-buku yang mereka pahami. Ada pula bagian di mana mereka harus menceritakan kembali. Terakhir, dilakukan pembimbingan dalam menuliskan judul buku dan nama tokoh yang paling disukai oleh masing-masing anak dari seluruh buku yang disediakan.

Sebagai bentuk apresiasi pada semangat dan keaktifan partisipasi anak-anak, dilakukan permainan dan kuis berkaitan dengan kegiatan membaca yang telah 
dilakukan.

Berikut adalah beberapa dokumentasi dari penyelenggaraan kegiatan PPM ini:

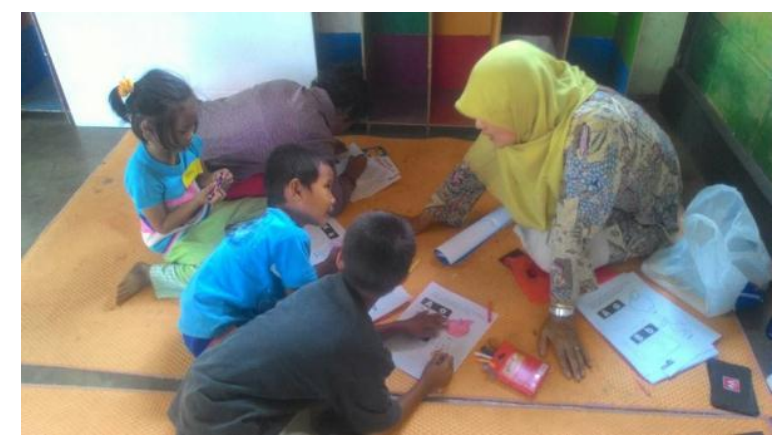

Gambar 1

Kegiatan Membaca

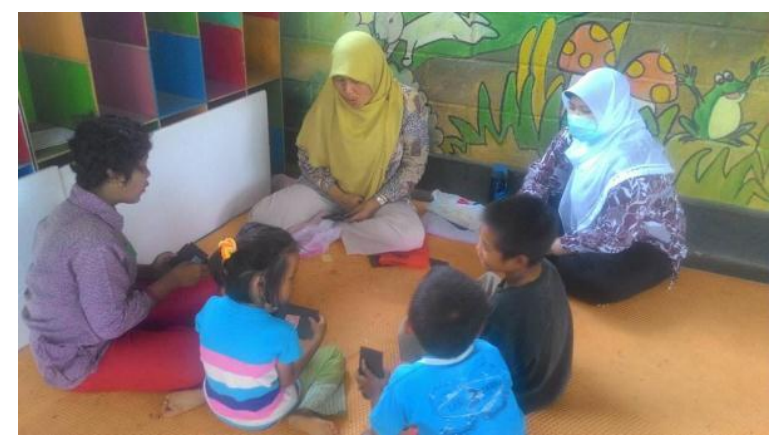

Gambar 2

Permainan

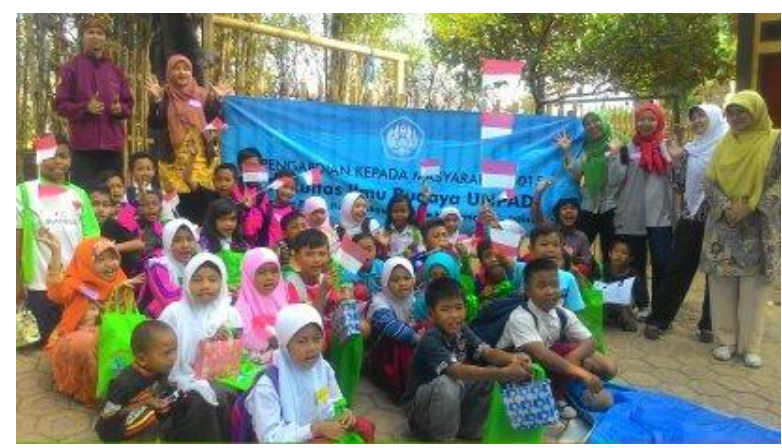

Gambar 1

Foto Bersama

Pada akhir kegiatan, anak-anak mendapatkan cendera mata berupa alat tulis dan makanan ringan, serta nasi kotak untuk para orang tua. Saat dilakukan evaluasi tentang hasil PPM ini, pada umumnya orang tua dan pihak sekolah (Bunda Hajar dan Taman Ilmu) menyatakan sikap positif. Mereka berharap kegiatan sejenis dapat diselenggarakan kembali pada kesempatan lain.

Dengan demikian, secara umum dapat dinyatakan bahwa kegiatan Pengabdian Kepada Masyarakat ini menunjukkan hasil baik dengan indikator meningkatnya minat baca para siswa PAUD Bunda Hajar Sukanegla Desa Hegarmanah Kecamatan Jatinangor. 


\section{SIMPULAN}

Minat baca merupakan hal yang sangat penting ditanamkan pada anak-anak sejak usia dini. Kegemaran membaca akan tertanam bila ada pembiasaan dari lingkungan sekitar (keluarga, sekolah, teman) sehingga anak akan memiliki minat baca yang kuat. Tinggi atau rendahnya minat baca tidak hanya berkaitan dengan pembiasaan namun juga dengan ketersediaan sarana yang sesuai dengan preferensi dan usia anak.

Secara umum, tanggapan masyarakat terhadap kegiatan PPM ini baik, sehingga seluruh rangkaian kegiatan dapat terlaksana dengan baik pula, dimulai dari tahap persiapan, pelaksanaan, hingga tahap evaluasi. Peran Perguruan Tinggi memang sudah selayaknya lebih ditingkatkan dalam upaya pemberdayaan masyarakat, agar nilai maslahat dari sebuah pendidikan dapat dinikmati oleh semua kalangan.

\section{DAFTAR RUJUKAN}

Berger, Peter L. dan Thomas Luckmann. 1990. Tafsir Sosial Atas Kenyataan: Risalah Tentang Sosiologi Pengetahuan. Jakarta: LP3ES.

Herawati, Netti. 2005. Buku Pendidik Pendidikan Anak Usia Dini. Yogyakarta: Mizania.

Tilaar, H.A.R. 2002.Membenahi Pendidikan Nasional. Jakarta: Rineka Cipta.

Sutrisno, Edy. 2009. Manajemen Sumber Daya Manusia. Jakarta: Kencana

Somadayo, Samsu. 2011. Strategi dan teknik pembelajaran membaca. Yogyakarta: Graha Ilmu

Sutrisno, Edy.2009. Manajemen Sumber Daya Manusia. Jakarta: Kencana.

Tarigan, Henry Guntur. 2008. Membaca Sebagai Suatu Keterampilan Berbahasa. Bandung: Angkasa

Tilaar, H.A.R. 2002. Membenahi Pendidikan Nasional. Jakarta: Rineka Cipta

http://referensi.data.kemdikbud.go.id/ 
Intan, Penelitian Tindakan Kelas....105 